\title{
SONDEOS ESTRATIGRÁFICOS EN LA ALJAFERÍA DE ZARAGOZA (OCTUBRE-DICIEMBRE 1983)
}

\author{
Por \\ ENRIQUE ARIÑO GIL \\ $Y$ \\ JUAN ANTONIO SOUTO LASALA
}

De entre las labores de investigación y documentación previas a las obras de restauración llevadas a cabo estos últimos años en el palacio de la Aljafería (Zaragoza), nos referiremos brevemente a los sondeos estratigráficos realizados entre los meses de octubre y diciembre de 1983 (1).

Los objetivas fundamentales de estos sondeos fueron tres: el primero de ellos, la obtención de perfiles estratigráficos que mostrasen la evolución de este sector del palacio desde sus orígenes hasta el siglo XX - recuérdese que la Aljafería fue utilizada como cuartel hasta fecha muy reciente (2)--; los dos restantes, claramente vinculados al primero, la prospección de posibles estructuras islámicas en la zona y la consideración de la idoneidad o no de una posible excavación metódica de este patio. Todo ello con el fin primordial de lograr un mejor conocimiento del edificio en general y del sector occidental en particular, ya que el único resto arquitectónico de época islámica documentado en él hasta la fecha es un fragmento de fundación de un cubo de planta presumiblemente ultrasemicircular, recientemente descubierto en el ángulo noroccidental del palacio al realizar obras de limpieza.

El desarrollo de los sondeos se llevó a cabo mediante la excavación de tres catas de 20 metros de longitud y 3,50 de ancho que, partiendo del muro que limita el interior del patio por el sur, se desarrollan paralelamente al homólogo oriental. De esta forma, los sondeos abarcarian teóricamente desde la fundación del cuartel hasta un punto bien entrado en la superficie del patio (fig. 1 ). La excavación se proyectó, en principio, para ser realizada por niveles, dando prioridad al sentido horizontal sobre el vertical. De esta manera, los primeros 40-50 centímetros dieron como resultado un conjunto de pequeños estratos, correspondiendo todos ellos a una serie de remociones que en principio estima-

(1) Queremos dejar testimonio de nuestro más profundo agradecimiento al Dr. D. Angel Peropadre Muniesa, arquitecto restaurador de la Aljafería. En cuanto a los resultados de la campaña, el presente opúsculo no es sino un breve avance, $\gamma$ su contenido no ha de considerarse en modo alguno como definitivo.

(2) La publicación más asequible y actualizada para una introducción general al estudio histórico-artístico de la Alja fería es la de BORRÁS GUALIS, G. M., uZaragoza musulmanan, en FATAS, G., coord., Guia histórico-artística de Zaragoza, Zaragoza, 1982, pp. 61.92 , esp. pp. 64 y ss. Se hallará una bibliografia detallada en las pp. $91-2$ 
mos como de superficie y ajenas a contextos arqueológicos precisos. Al mismo tiempo se iba poniendo al descubierto una serie de estructuras de calidad paupérrima y cronología reciente. Ante el escaso in terés de estos resultados, se resolvió realizar un sondeo en profundidad en cada una de las catas 1 y 2 , alli donde no aparecian restos arquitectónicos, con el fin de documentar las estratigrafías y dejar para más adelante la excavación metódica del resto. De estas estratigrafías nos referiremos brevemente a la que en la figura 1 se indica entre las letras $A$ y $B$ (fig. 2).

Tal como puede inferirse del estudio de la figura 2, el principal problema con el que se ha contado es la inexistencia de niveles de ocupación intactos. Aunque los datos aportados por la estratigrafía que presentamos en esta noticia quedan incompletos al faltar las demás, que la clarifican y complementan, son suficientemente elocuentes: sobre un nivel natural de sedimentos terciarios abundantes en grava y cantos rodados se asienta un estrato doble cuyo material, en proceso de estudio, parece revelar una datación bajomedieval para lo que es el estrato en sí, apareciendo también cerámicas romanas - sigillatas hispánicas tardías - e islámicas en una proporción ínfima y en estado to talmente fragmentario. Se trataría, en última instancia, de un nivel revuelto. Inmediatamente por encima de él se extiende otro, abundante en ceniza, con el que concluye la estratigrafía "horizontal" de este corte. El resto de los niveles, como puede apreciarse, consiste en una serie de añadidos formando el estrato revuelto de superficie al que ya nos hemos referido. Es necesario destacar que los tres niveles inferiores, e incluso el substrato natural de sedimentos terciarios, se han visto profundamente alterados por intrusiones estratigráficas que nosotros, hoy por hoy, a sabiendas de la utilización castrense del palacio y a la vista de su morfología y del material que han proporcionado, creemos identificar como zanjas abiertas en el suelo del patio y destinadas posiblemente a prácticas de instrucción militar. En su momento habremos de relacionar esta estratigrafía con las restantes y con los restos arquitectónicos hasta ahora exhumados, para los que presumimos una utilización análoga.

Se concluye, por estos datos brevemente expuestos, que las reformas $y$ avatares por que pasó la Aljafería a lo largo de su historia dejaron huella en la arquitectura y también en lo que hoy es subsuelo. No se han hallado, en el patio occidental, niveles intactos. Tampoco se ha dado, de momento, con restos arquitectónicos que puedan fecharse con cierta fiabilidad en otra época que no sea la contemporánea. Las cerámicas halladas dejan abierta la hipótesis de un posible asentamiento preislámico en el lugar o sus alrededores, aunque, como ya se ha indicado, no se ha encontrado material alguno en su lugar original, razón que hace permanecer en la incógnita la procedencia de los fragmentos de sigillata recuperados. Ignoramos por el momento la utilidad que debió tener este sector del palacio en época islámica (3).

Los sondeos realizados aportan una última consideración, relativa a la conveniencia o no de futuras excavaciones metódicas en una zona del palacio que parece mostrar un interés arqueológico ciertamente dudoso.

(3) Sobre la organización espacial de la Aljafería, v. el capitulo introductorio de la obra de EWERT, CH., Soanish-Is/amische Systeme sich Kreuzender Bögen. III. Die Aljafería in Zaragoza, 1." parte, Berlín, 1978, y el correspondiente plano n. $1 . V$. tb. del mismo, uTradiciones omeyas en la arquitectura palatina de la época de los taifas. La Aljafería de Zaragozan, Actas del XXIII Congreso Imternacional de Historia del Arte, Granada, 1973, t. H, Granada, 1977, pp. 62-75, pássim y fig. 1 . Nos han sido muy útiles los cambios de impresiones con el autor. 


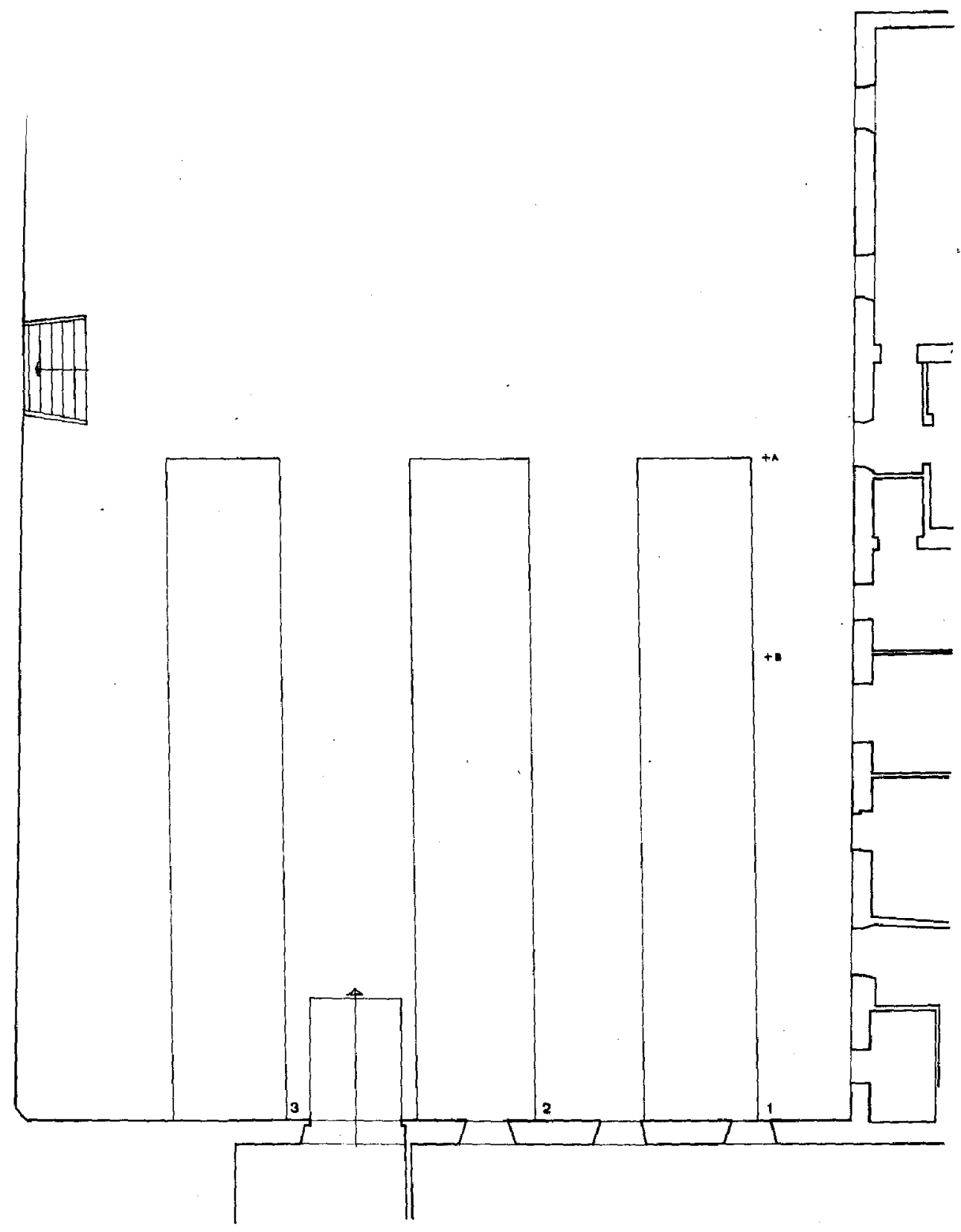

Figura 1. Detalle del patio occidental de la Aljafería con expresión de las zonas excavadas (sobre planimetría general de la planta 0, según A. Peropadrel. 


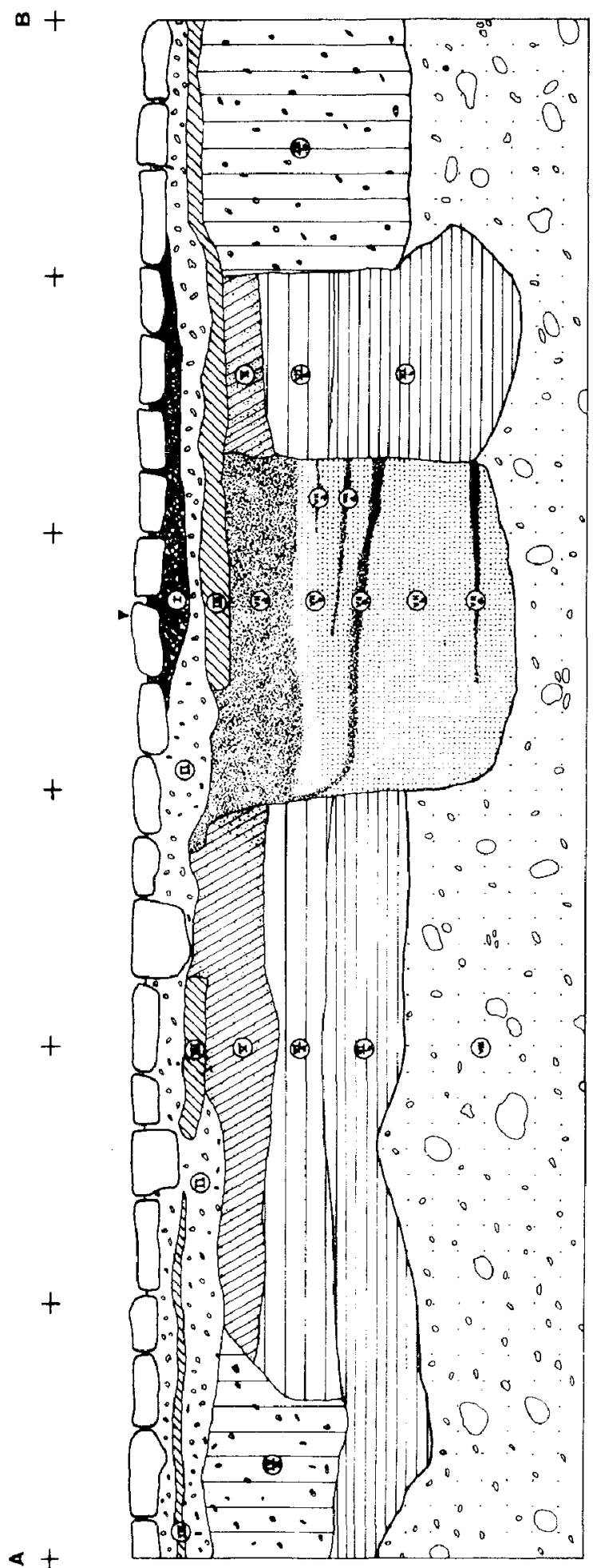

Figura 2.-Estratigrafía del perfil AB (E. Ariño - J. A Soutol 